\title{
Evaluation of the effect of diatomaceous earth as a sustainable alternative in commercial interest crops in Colombia
}

\author{
N. Escobar, J. Espejo \& L. Rodríguez \\ Grupo de investigación Área Verde, \\ Universidad de Cundinamarca, Colombia
}

\begin{abstract}
Current production of seasonal crops needs to have more efficient integrated handling to obtain expected returns, contribute to sustainability and the environment, as an alternative incorporating in bio-agricultural inputs. The aim of this research was to evaluate the effect of diatomaceous earth (TDDA) as bioinput, fertilization and biological control in commercial crops: corn (Zea mays), bean (Phaseolus vulgaris L.), carrot (Daucus carota L.) and yellow potato (Solanum phureja). We compared the following treatments: TDDA + commercial compost, TDDA + chemical fertilizer, TDDA + compost and control (traditional chemical). The fieldwork was conducted in private property located in Guchipas, a municipality of Pasca, (Cundinamarca department). We performed a Latin square design for each crop. Chemical analyses were made at the private Calderon's soil laboratory. For data processing we used MEANS in SAS statistical package (version 9.0). When a significant effect $(\alpha=0.05)$ was shown by the Tukey means test, significant differences between crops for physiological variables (leaf area index, relative growth rate, dry weight, fresh weight and height) were found $(\mathrm{P}<0.05)$. The best results for phenological variables and productivity were obtained for TDDA + chemical fertilizer, and TDDA + compost treatments. Pests as whitefly (T. vaporariorum) and thrips (Thrips tabaci) were controlled. Diatomaceous earth application allows the dose of chemical fertilizers, thereby promoting healthier environmental management. Keywords: diatomaceous earth, sustainability, commercial crops, productivity and environment.
\end{abstract}




\section{Introduction}

Organic fertilizers have been used since ancient times and their influence on soil fertility has been demonstrated, although chemical composition, contribution of nutrients to crops, and effect on soil vary according to origin, age, and management moisture content (Tester [1]). Diatomaceous earth is a product obtained from unicellular algae remains which are fossilized diatoms found mainly in sediment. TDDA consists in $65.61 \%$ of silicon dioxide $\left(\mathrm{SiO}_{2}\right)$ with 29 trace elements in different proportion (Gunes et al. [2]). Miligan and Morel [3] reported that TDAA can be used as a complement and not a substitute for agricultural inputs applied. The silica is not considered an essential element for plants, but is reported to benefit crops by inducing resistance and protection against biotic and abiotic environmental factors, and improving yields and quality of crops. Other studies [2, 4, 5], showed increased quality of soil by adding nutrients.

Environmental pollution and productive soil implement alternatives that do not alter the balance of the system giving rise to the expected beneficial in soil and the environment. In this context, this research had a special interest in implementing diatomaceous earth or diatomite as a bioinput in the Sumapaz area. For these reasons, this study aims to answer the following question: What is the effect of using diatomaceous earth as a bioinput in commercial crops (corn, beans, carrots and yellow potatoes) under environmental conditions of the municipality of Pasca?

\section{Methodology}

\subsection{Study area}

The private land for evaluating diatomaceous earth (TDDA) is located in Guchipas village, which is approximately 2 kilometers from the municipality of Pasca (Cundinamarca department). Agricultural production is completely rural; the main crops being onions, beans, corn, potato, tomato, peas, carrots and blackberries. Guchipas is 1900 meters above sea level, with a cold-temperate climate and temperatures of between 16 and $18^{\circ} \mathrm{C}$.

\subsection{Experimental design}

This research took place in an area of $308 \mathrm{~m}^{2}$, where the following species were planted and evaluated: maize (Zea mays), bean (Phaseolus vulgaris L.), carrot (Daucus carota L.) and yellow potato (Solanum phureja). We compared the following treatments: TDDA + commercial compost, TDDA + chemist fertilizer, TDDA + compost, and a control (traditional chemical). We used a Latin square design for each crop and every treatment had four replicates in 10 experimental units. This type of design is used to conduct experiments under heterogeneous conditions where the properties change in two directions. Experimental units were grouped in two directions (rows and columns) and were treated randomly. 
To evaluate treatment, the GLM procedure in a SAS statistical package (version 9.0) was applied.

\subsection{Field phase}

Seeds of species were mixed with diatomaceous earth 24 hours before sowing. The bio-input ratio used was $15 \mathrm{~g}$ per $\mathrm{kg}$ of seed; the seeds were mixed in dry. Four fertilizers were divided over different plant vegetative states; these fertilizers were put on, on the same date for different crops.

The leaf areas - fresh and dry weight - were taken after fertilization, in order to obtain the performance of physiological and morphological variables for comparative analysis of each treatment by using the bio-input. Best treatment on yields was determined by counting pods per plant, weight and number of grains per pod (for the beans case), weight and number of ears (for corn), and weight and number (for carrot and yellow potatoes).

The use of crop protection products was given under the parameters of visual damage (severity) and the incidence of different pests and diseases, field annotations were made for monitoring pests during the crop growth.

\subsection{Laboratory phase}

The chemical parameters (OM, OC, macro and microelements) were determined in the private Calderon's soil laboratory.

\section{Results and discussion}

\subsection{Chemical parameters}

The elemental composition of fertilizer is shown in table 1. Organic matter $(\mathrm{OM})$, was significantly higher $(\mathrm{P}<0.05)$ in soil after fertilization $(15.76 \%)$. As indicated by Huang et al. [6], the value of the compost mixed with TDDA in all forms comes from contributing the soil organic matter, with optimum values of between 15 and $35 \%$, thereby increasing water retention capacity; being a rich source of nutrients for plants. The range of values mentioned is close to those obtained.

The three macro-nutrients $(\mathrm{NPK})$ show differences significantly $(\mathrm{P}<0.05)$ higher after fertilization. These results show a similar trend to that reported by Paredes et al. [7], where $\mathrm{P}$ and $\mathrm{K}$ contents are higher in mixtures with animal manure fertilization. After fertilization the soil shows better chemical conditions. One factor that influenced and its increase was the incorporation of organic matter into compost applications, because they produced humic substances chemically and biologically modified, constituting the most active fraction of organic matter to most organic reactions. Other results $[8,9]$, showed chemical conditions in soil after fertilization. 
Table 1: Results of chemical parameters before and after fertilization.

\begin{tabular}{|l|c|c|c|}
\hline \multicolumn{1}{|c|}{ Parameters } & Unit & $\begin{array}{c}\text { Before } \\
\text { fertilization }\end{array}$ & $\begin{array}{c}\text { After } \\
\text { fertilization }\end{array}$ \\
\hline Organic matter & $\% \mathrm{OM}$ & $13.21 \mathrm{~b}$ & $15.76 \mathrm{a}$ \\
\hline $\mathrm{pH}$ & & $5.4 \mathrm{a}$ & $5.9 \mathrm{a}$ \\
\hline Potassium & $\% \mathrm{~K}$ & $0.36 \mathrm{~b}$ & $0.73 \mathrm{a}$ \\
\hline Nitrogen & $\% \mathrm{~N}$ & $30 \mathrm{~b}$ & $40 \mathrm{a}$ \\
\hline Phosphorus & $\% \mathrm{P}$ & $28 \mathrm{~b}$ & $34 \mathrm{a}$ \\
\hline Calcium & $\mathrm{meq} / 100 \mathrm{~g}$ & $4.31 \mathrm{~b}$ & $5.18 \mathrm{a}$ \\
\hline Magnesium & $\mathrm{meq} / 100 \mathrm{~g}$ & $1.17 \mathrm{a}$ & $2.0 \mathrm{a}$ \\
\hline Iron & $\mathrm{meq} / 100 \mathrm{~g}$ & $136 \mathrm{~b}$ & $150 \mathrm{a}$ \\
\hline Sodium & $\mathrm{meq} / 100 \mathrm{~g}$ & $0.37 \mathrm{~b}$ & $1.45 \mathrm{a}$ \\
\hline Manganese & $\mathrm{meq} / 100 \mathrm{~g}$ & $13.21 \mathrm{~b}$ & $14.76 \mathrm{a}$ \\
\hline
\end{tabular}

Different letters indicate significant differences $(\mathrm{P}<0.05)$.

\subsection{Phenological variables}

In all crops, the process of seed germination can be affected by seed quality, the environmental conditions (water, temperature, oxygen and light), free seed dormancy and absence of pathogens (Salisbury and Ross [10]).

We found germination percentages in all crops with TDDA + compost was significantly higher $(\mathrm{P}<0.05)$ than other treatments (Tables 2, 3, 4 and 5). One reason implies that the organic fertilizers in such compost have a lot of moisture which is absorbed by the generating seed germination in less time; the use of good quality seeds also supports. The poor quality seeds have poor growth and vigor which is affected by external factors such as nutrition of the mother plant, mechanical damage caused by processing, and seed storage that can be important in establishing a culture (Vargas et al. [11]).

Table 2: Corn phenological variables.

\begin{tabular}{|c|c|c|c|c|c|}
\hline Treatments & $\begin{array}{c}\text { Germination } \\
(\%)\end{array}$ & $\begin{array}{c}\text { Leaf area } \\
\text { Index }\end{array}$ & $\begin{array}{c}\text { Relative } \\
\text { growth rate }\end{array}$ & $\begin{array}{c}\text { Fresh } \\
\text { weight } \\
(\mathrm{g})\end{array}$ & $\begin{array}{c}\text { Dry } \\
\text { Weight } \\
(\mathrm{g})\end{array}$ \\
\hline $\begin{array}{c}\text { TDDA + chemical } \\
\text { fertilizer }\end{array}$ & $95.2 \mathrm{a}$ & $0.17 \mathrm{ab}$ & $0.098 \mathrm{a}$ & $86.3 \mathrm{a}$ & $19 \mathrm{a}$ \\
\hline $\begin{array}{c}\text { TDDA+commercial } \\
\text { compost }\end{array}$ & $78.3 \mathrm{bc}$ & $0.15 \mathrm{bc}$ & $0.030 \mathrm{c}$ & $76.4 \mathrm{c}$ & $9.9 \mathrm{c}$ \\
\hline \begin{tabular}{c} 
TDDA + compost \\
\hline $\begin{array}{c}\text { Control-traditional } \\
\text { chemical }\end{array}$
\end{tabular} & $84.3 \mathrm{a}$ & $0.21 \mathrm{a}$ & $0.08 \mathrm{~b}$ & $85.4 \mathrm{a}$ & $18.2 \mathrm{~b}$ \\
\hline
\end{tabular}

Different letters indicate significant differences $(\mathrm{P}<0.05)$. 
Table 3: Bean phenological variables.

\begin{tabular}{|c|c|c|c|c|c|}
\hline Treatments & $\begin{array}{c}\text { Germination } \\
(\%)\end{array}$ & $\begin{array}{c}\text { Leaf area } \\
\text { index }\end{array}$ & $\begin{array}{c}\text { Relative } \\
\text { growth rate }\end{array}$ & $\begin{array}{c}\text { Fresh } \\
\text { weight } \\
(\mathrm{g})\end{array}$ & $\begin{array}{c}\text { Dry } \\
\text { weight } \\
(\mathrm{g})\end{array}$ \\
\hline $\begin{array}{c}\text { TDDA + chemical } \\
\text { fertilizer }\end{array}$ & $93.6^{\mathrm{b}}$ & $0.016 \mathrm{a}$ & $0.07 \mathrm{a}$ & $28.9 \mathrm{a}$ & $29.98 \mathrm{a}$ \\
\hline $\begin{array}{c}\text { TDDA+commercial } \\
\text { compost }\end{array}$ & $92.9^{\mathrm{b}}$ & $0.013 \mathrm{~b}$ & $0.044 \mathrm{c}$ & $15.9 \mathrm{c}$ & $19.93 \mathrm{c}$ \\
\hline $\begin{array}{c}\text { TDDA + compost } \\
\text { Control-traditional } \\
\text { chemical }\end{array}$ & $92.4 \mathrm{~b}$ & $0.011 \mathrm{~b}$ & $0.059 \mathrm{bc}$ & $19.3 \mathrm{~b}$ & $22.1 \mathrm{bc}$ \\
\hline
\end{tabular}

Different letters indicate significant differences $(\mathrm{P}<0.05)$.

Table 4: Carrot phenological variables.

\begin{tabular}{|c|c|c|c|c|c|}
\hline Treatments & $\begin{array}{c}\text { Germination } \\
(\%)\end{array}$ & $\begin{array}{c}\text { Leaf area } \\
\text { index }\end{array}$ & $\begin{array}{c}\text { Relative } \\
\text { growth rate }\end{array}$ & $\begin{array}{c}\text { Fresh } \\
\text { weight } \\
(\mathrm{g})\end{array}$ & $\begin{array}{c}\text { Dry } \\
\text { weight } \\
(\mathrm{g})\end{array}$ \\
\hline $\begin{array}{c}\text { TDDA + chemical } \\
\text { fertilizer }\end{array}$ & $63.4 \mathrm{ab}$ & $0.013 \mathrm{a}$ & $0.05 \mathrm{ab}$ & $48.9 \mathrm{a}$ & $43.8 \mathrm{a}$ \\
\hline $\begin{array}{c}\text { TDDA+commercial } \\
\text { compost }\end{array}$ & $45.9 \mathrm{c}$ & $0.010 \mathrm{~b}$ & $0.022 \mathrm{c}$ & $32.9 \mathrm{c}$ & $34.7 \mathrm{c}$ \\
\hline \begin{tabular}{c} 
TDDA + compost \\
\hline $\begin{array}{c}\text { Control-traditional } \\
\text { chemical }\end{array}$
\end{tabular} & $52.9 \mathrm{a}$ & $0.011 \mathrm{ab}$ & $0.07 \mathrm{a}$ & $42.4 \mathrm{~b}$ & $41.8 \mathrm{ab}$ \\
\hline
\end{tabular}

Different letters indicate significant differences $(\mathrm{P}<0.05)$.

Table 5: Yellow potato phenological variables.

\begin{tabular}{|c|c|c|c|c|c|}
\hline Treatments & $\begin{array}{c}\text { Germination } \\
(\%)\end{array}$ & $\begin{array}{c}\text { Leaf area } \\
\text { Index }\end{array}$ & $\begin{array}{c}\text { Relative } \\
\text { growth rate }\end{array}$ & $\begin{array}{c}\text { Fresh } \\
\text { weight } \\
(\%)\end{array}$ & $\begin{array}{c}\text { Dry } \\
\text { Weight } \\
(\%)\end{array}$ \\
\hline $\begin{array}{c}\text { TDDA + chemical } \\
\text { fertilizer }\end{array}$ & $76.7 \mathrm{ab}$ & $0.18 \mathrm{ab}$ & $0.08 \mathrm{~b}$ & $57.7 \mathrm{a}$ & $31.3 \mathrm{ab}$ \\
\hline $\begin{array}{c}\text { TDDA+commercia } \\
\text { l compost }\end{array}$ & $73.9 \mathrm{ab}$ & $0.13 \mathrm{bc}$ & $0.06 \mathrm{c}$ & $46.4 \mathrm{a}$ & $29.9 \mathrm{a}$ \\
\hline \begin{tabular}{c} 
TDDA + compost \\
\hline $\begin{array}{c}\text { Control-traditional } \\
\text { chemical }\end{array}$
\end{tabular} & $78.7 \mathrm{a}$ & $0.21 \mathrm{a}$ & $0.09 \mathrm{a}$ & $45.4 \mathrm{a}$ & $28.2 \mathrm{a}$ \\
\hline
\end{tabular}

Different letters indicate significant differences $(\mathrm{P}<0.05)$. 
Compost applied was a mix of chicken and cattle manure. The results obtained could be due to fertilizers and chicken manure; they are the best nitrogen-fixing providing nutrients to soil and have positive influences on soil structure. Sánchez et al. [12] mentioned that manure can alter the microbial population allowing a greater exchange of nutrients by the formation of aggregates at the roots of plants.

In general, the best results of the growth variables in the vegetative stage occurred in the TDDA + chemical treatment, partly due to the chemical components and their contribution containing minerals in the soil. Also TDDA + compost has important results, indicating that the organic fertilizer effect was almost similar to the chemical, allowing an alternative fertilization to generate, especially in corn, beans and carrots. Bernal et al. [13] conducted an assessment of the effect of mineral and organic fertilizer (manure) on growth and yield of maize and beans, achieving the best returns in the manure treatment. Other studies [14-17] showed that compost is an alternative fertilizer.

A constant behavior in the early stages of plants was shown, probably due to production of sheets which could be synthesized by a charge of nutrients. Barraza et al. [18] and Abad et al. [19] reported a correlation between the process of growth and development of various parts of the plant, which can be explained in terms of supply and demand, so it is spending its reserves mainly endospermically and additionally begins to extract the nutrients available in the soil. As a result, the metabolism is accelerated in order to produce the carbon skeletons for growth.

\subsection{Productivity}

The best treatments measured by crop yields were TDDA + chemical fertilizer for carrots and corn (table 6). TDDA + compost for beans, and Traditional chemical for potatoes, TDDA + commercial compost treatment, shows significant differences $(\mathrm{P}<0.05)$, probably for nutrient deficiencies.

The crop yields are seriously compromised by environment conditions, such as weed presence, low solar radiation, relative humidity, water retention, genetic soil type and fertilization. The crop yield reduction also is determined by distribution of assimilates produced in the secondary structures during the initial development phase, where it competes strongly for available assimilates to developing fruits (Biederbeck et al. [20]).

For the beans crops, TDDA + compost was better. Estrada and Peralta [21] show two types of organic fertilizers (chicken manure and cow manure) and mineral growth and crop yield of the common bean (Phaseolus vulgaris L.) variety DOR-364: the best results with organic fertilizers, mentioned that the presence of organic substrates in both instances (bioassay, rhizosphere) enhance the growth of microorganisms (especially bacteria), which immobilize nutrients to increase biomass. Immobilized nutrients can be available to other microorganisms and plants during their growth cycle. Other studies [22, 23], reported an increase of productivity by using compost in crops systems. 
Table 6: Crop yields.

\begin{tabular}{|c|l|r|l|l|l|l|l|}
\hline Crops & \multicolumn{2}{|c|}{ Corn } & \multicolumn{2}{c|}{ Bean } & Carrot & \multicolumn{2}{|c|}{ Yellow potatoes } \\
\hline Treatments & $\begin{array}{c}\text { ears } \\
\text { no. }\end{array}$ & $\begin{array}{c}\text { ears } \\
\text { wt.(g) }\end{array}$ & $\begin{array}{l}\text { pods } \\
\text { no. }\end{array}$ & $\begin{array}{c}\text { pods } \\
\text { wt. (g) }\end{array}$ & wt. (g) & no. & $\begin{array}{c}\text { wt. } \\
\text { (g) }\end{array}$ \\
\hline $\begin{array}{c}\text { TDDA+ } \\
\text { chemical } \\
\text { fertilizer }\end{array}$ & $2.1 \mathrm{a}$ & $397.5 \mathrm{a}$ & $19.5 \mathrm{a}$ & $40.1 \mathrm{~b}$ & $84.9 \mathrm{a}$ & $8.4 \mathrm{ab}$ & $58.3 \mathrm{ab}$ \\
\hline $\begin{array}{c}\text { TDDA+ } \\
\text { commercial } \\
\text { compost }\end{array}$ & $1.4 \mathrm{~b}$ & $299.2 \mathrm{c}$ & $10.1 \mathrm{c}$ & $37.2 \mathrm{~b}$ & $65.5 \mathrm{c}$ & $5.3 \mathrm{bc}$ & $49.9 \mathrm{c}$ \\
\hline $\begin{array}{c}\text { TDDA+ } \\
\text { compost }\end{array}$ & $2.0 \mathrm{a}$ & $378 \mathrm{ab}$ & $18.2 \mathrm{ab}$ & $41.3 \mathrm{a}$ & $72.8 \mathrm{ab}$ & $5.4 \mathrm{bc}$ & $55.2 \mathrm{ab}$ \\
\hline $\begin{array}{c}\text { Control- } \\
\text { traditional } \\
\text { chemical }\end{array}$ & $1.7 \mathrm{~b}$ & $303.2 \mathrm{~b}$ & $15.7 \mathrm{~b}$ & $39.6 \mathrm{ab}$ & $77.9 \mathrm{~b}$ & $9.7 \mathrm{a}$ & $65.7 \mathrm{a}$ \\
\hline
\end{tabular}

Different letters indicate significant differences $(\mathrm{P}<0.05)$.

Organic fertilizers can be an alternative to replace inorganic fertilizer, as indicated above, additionally to supplying organic fertilizers to the soil with nutrients like $\mathrm{N}$ and other essential elements contained in the compost and TDDA. De Bertoldi et al. [24], Eghball et al. [25] and Illner et al. [26] indicated that manure mineralized at around $70 \%$ after the first year of application, and residual soil effects over two years and that remaining was transformed into humus, which is incorporated into the soil and produces a beneficial effect in the structure of the soil during the first year.

Only yellow potato crops showed better results with chemical fertilizer; this might be caused by demands of crop, seed quality and environmental conditions. Rodríguez and Ñ́stez [27] found that chemical fertilizer components in potato crops were slowly absorbed, thus allowing the continuous incorporation of minerals in the ground and reflecting an increased production.

\subsection{Biological control}

The higher incidence of crop pests in beans showed similar proportions in each treatment, especially whitefly and thrips (Thrips tabaci). The diatomaceous earth combined with natural or chemical insecticides acting effectively control the whitefly (Trialeurodes vaporariorum), reducing significantly pest populations and avoiding damage of the cultivation. The products are effective in controlling adults but not in the stationary state of the pest.

Diatomaceous earth seems to be a good biological control in beans, probably by its composition, especially silicon. Goren et al. [28] reported that the presence of silicon benefited crop resistance, and induction of protection against biotic and abiotic environmental factors. Other studies [29, 30] indicated that apparently the 
role of silicon has been attributed in part to its accumulation and polymerization in cell walls which provides a mechanical barrier against attack by pathogens and pests as well as being an accumulator of compounds that generate natural plant reactions to a decrease in insect attack. In organic agriculture it is used as a natural pesticide to combat non-poisonous and external parasites on pets, directly applying powder on the animal's hair.

\section{Conclusions}

The results of our study showed that the best treatments measured by crop yields were TDDA + chemical fertilizer. The diatomaceous earth combined with natural or chemical insecticides acting effectively control the whitefly (Trialeurodes vaporariorum), reducing significantly pest populations and avoiding damage of the cultivation. Diatomaceous earth has reduced doses of chemical fertilizers on crops of commercial interest, and thus becomes an alternative environmental management to contribute to the reduction of chemicals in air, water and soil. We should continue to evaluate doses, fertilizers and effects they can generate diatomaceous earth in tropical crops in different climatic conditions.

\section{Acknowledgements}

The authors thank the Universidad de Cundinamarca for providing laboratory space. We also thank to AGROPULI for financial support.

\section{References}

[1] Tester, C., Organic amendment effects on physical and chemist properties of a sandy soil. Soil sci. Soc. J., 19(54), pp. 827-831, 1990.

[2] Gunes, A., Inal, A., Bagci, E. G., \& Pilbeam, D., Silicon-mediated changes of some physiological and enzymatic parameters symptomatic for oxidative stress in spinach and tomato grown in sodic- $\beta$ toxic soil. Plant Soil, pp. 290: 103-114, 2007.

[3] Milligan, A. J., Morel, F. M., A Proton Buffering Role for Silica in Diatoms. Science, 29(7), pp. 1848-1850, 2002.

[4] Horna, Z., Resultados de la aplicación de varias dosis de Silicio inorgánico en sinergismo con Biol y Mezcla fix HS K36. Hda. Revista medio ambiente, pp. 30-22, 2007.

[5] Matichenkov, V., Silicon in Food. Agriculture and Environment. International Conference and Exhibition, pp. 35-39, 2005.

[6] Huang, G. F., Wu, Q. T., Wong, J. W., \& Nagar B. B., Transformation of organic matter during co-composting of pig manure with sawdust. Bioresour. Technol., 16 (97), pp. 1834-1842, 2006.

[7] Paredes, C., Roig, A. M., Bemal, P. P., Sánchez, M. A., \& and Cegarra, J., Evolution of organic matter and nitrogen during co-composting of olive 
mill wastewater with solid organic wastes. Biol. Fértil. Soils, (20), pp. 226-236, 2000.

[8] Raviv, M., Medina, S., Krasnovsky, A., \& Ziadna, H., Organic matter and nitrogen conservation in manure compost for organic agriculture. Compost Sei. Util, 12(1), pp. 6-10, 2004.

[9] Shannon, D., Sen, A. M. \& Johnson, D. B., A comparative study of the microbiology of soils managed under organic and conventional regimes. Soil Use Manage, 18, pp. 274-283, 2002.

[10] Salisbury, F. B., \& Ross, C. W., Fisiología vegetal (capitulo 5). Tejidos vegetales, ed. Grupo Editorial Iberoamérica, México D.F., pp. 760, 2004.

[11] Vargas, S. A., Becker, C., Oddino, M., Zuza, A., \& March, G., Soil biological, chemical and physical responses to the impact of tillage intensity, fertilization, and cattle grazing in a long-term field trial. Environ. Manag. 44, pp. 378-376, 2009.

[12] Sánchez, M. A., Roig, A., Paredes, C., \& and Bernal, M. P., Nitrogen transformation during organic waste composting by the rutgers system and its effects on $\mathrm{pH}, \mathrm{EC}$ and maturity of the composting mixtures. Biores. Technol., 78(3), pp. 301-308. 2001.

[13] Bernal, M. P., Alburquerque, J. A., \& Moral R., Composting of animal manures and chemist criteria for compost maturity assessment. A review. Bioresource technology. pp. 5444-5453, 2009.

[14] Inbar, Y., Hadar, Y., \& Chen, Y., Recycling of cattle manure. The composting process and characterization of maturity. J. Environment Quality, 22. pp. 857-863, 2000.

[15] Lazcano, C., Gómez, M., \& Domínguez, J., Comparison of the effectiveness of composting and vermicomposting for the biological stabilization of cattle manure. Chemosphere, (72), pp. 1013-1019, 2008.

[16] Chenet, L., Dick, W., Streeter, J. G., \& Hoitink, H. A., Ryegrass utilization of nutrients released from composted biosolids and cow manure. Compost science, 4(1), pp. 73-83, 1996.

[17] Ross, M., García, C., \& Hernández, T., A full-scale study of treatment of pig slurry by composting: Kinetic changes in chemist and microbial properties on sorghum crops. Waste Manage, 15(26), pp. 1108-1118, 2006.

[18] Barraza, F., Fischer, C., \& Cardona, C., Estudio del proceso de crecimiento del cultivo del tomate (Lycopersicon esculentum Mill.) en el valle del Sinú medio, Colombia. Revista Agropecuaria de Colombia, pp. 96-85, 2004.

[19] Abad, M., Noguera, P., \& Carrión C., Los sustratos en los cultivos sin suelo. Tratado de cultivos sin suelo. Ediciones Mundi, pp. 113-158, 2004.

[20] Biederbeck, V. O., Campbell, C.A., \& Zenter, R. P., Effect of crop rotation and fertilization on some biological properties of a loam in southwestern Saskatchewan. Can. J. Soil Sci. 64, pp. 335-367, 1994.

[21] Estrada, M. E., \& Peralta, J. R., Evaluación de dos tipos de fertilizantes orgánicos (gallinaza y estiércol vacuna) y un mineral en el crecimiento y 
rendimiento del cultivo de frijol común (Phaseolus vulgaris L.) variedad DOR-364, postrera. Revista Agraria de Nicaragua, pp. 29-34. 2001.

[22] Adeniran, J. A., Taiwo, L. B., \& Sobulo, R. A., Effects of Organic wastes and Method of composting on compost maturity, Nutrient Composition of Compost and Yields of Two Vegetable Crops. J. of Sustainable Agriculture, 22(12), pp. 95-101, 2003.

[23] Benito, M., Masaguer, A., Moliner, A., Arrigo, N. \& Palma, R. M., Chemical and microbiological parameters for the characterisation of the stability and maturity of pruning waste compost. Biol fertil soils, 83(7), pp. 184-189, 2003.

[24] De Bertoldi, M., Vallini, G. \& Pera, A. The biology of composting: a review. Waste manage. res. 3(1), pp. 157-176. 2003.

[25] Eghball, B., Ginting, D., \& Gilley, J. E., Residual Effects of Manure and Compost Applications on Corn Production and Soil Properties. Agron. J. 18(96), pp. 442-447, 2004.

[26] Illner, P. P., Otto, A., Mair, J., \& Farbmacher, S., Chemist and Biochemist Parameters During Composting of Lawn Clippings with Special Regard to the Efficiency of a Compost Starter Kit. Compost Science \& Utilization, 15(1), pp. 40-46, 2007.

[27] Rodríguez, L., G., \& Ñústez, C. E., Influencia del espaciamiento entre plantas sobre la morfología y el crecimiento de la papa (Solanum tuberosum L. cv. Parda pastusa) bajo dos ambientes contrastantes. Agronomía Colombiana, 21(3), pp. 210-219, 2003.

[28] Goren, N., Sharon, G., Melemed, Y., \& Kislev, M., Nuts, nut cracking and pitted stones at Gesher Benot Ya'aqov, Israel. Proceedings of the National Academy of Science, pp. 2455-2460, 2002.

[29] Sastrosiswojo, S., Trips on vegetables in Indonesia. Agronomic research of Indonesia, 14(12), pp. 14-16, 2003.

[30] Epstein, E., Silicon. Annu. Rev. Plant Physiol. Plant Mol. Biol, 50(3), pp. 641-664, 2000. 